\title{
STRATEGI ETIOPIA DALAM MENGURANGI KETERGANTUNGAN TERHADAP BANTUAN LUAR NEGERI
}

\author{
Devita Prinanda \\ Program Studi Hubungan Internasional \\ Fakultas Ilmu Sosial Ilmu Politik, Universitas Muhammadiyah Malang \\ Email: devitaprinanda@umm.ac.id
}

\begin{abstract}
ABSTRAK
Negara di Afrika memiliki sejarah ketidakstabilan politik yang berdampak pada pertumbuhan ekonomi yang tidak maksimal. Karena ketidakstabilan tersebut maka banyak negara Afrika yang menerima bantuan luar negeri untuk merestrukturisasi ekonomi nasionalnya. Dampak dari bantuan yang diterima adalah pertumbuhan ekonomi dan perbaikan performansi nasional. Namun, disisi lain ternyata bantuan luar negeri membuat negara-negara di Afrika ketergantungan dengan bantuan tersebut. Etiopia adalah salah satu negara dengan penerima donor terbesar. Etiopia bergantung pada bantuan luar negeri hingga mencapai 50\% untuk anggaran nasional di tahun 2012. Namun, di tahun 2017 Etiopia mampu mengurangi ketergantungannya akan bantuan asing meskipun tetap sebagai negara penerima bantuan terbesar di Afrika. Penelitian ini membahas strategi Etiopia untuk melepaskan diri dari ketergantungan bantuan asing. Penulis menganalisa dengan menggunakan konsep strategi dalam mengurangi ketergantungan terhadap bantuan yang diinisasikan oleh Bräutigam dan Kwesi Botchwey. Hasil penelitian menunjukkan Etiopia mengalami pertumbuhan ekonomi yang cukup kuat. Permasalahan pangan dan isu penting lainnya mampu teratasi secara perlahan. Namun, peran besar dalam membantu Etiopia menjadi mandiri ada pada pendonor dan pihak eksternal. Keterlibatan donor dalam mengevaluasi bantuan membuat bantuan menjadi lebih efektif. Kolaborasi pendonor dalam melakukan bantuan baik dengan aktor pemerintah maupun non pemerintah juga menjadi kunci efektifitas implementasi proyek bantuan asing di Etiopia.
\end{abstract}

Kata kunci: Etiopia, foreign aid, Aid dependence, Strategi

\section{ABSTRACT}

Africa experienced political instability that rooted to economic development. Because of the instabilility, there were African States that restructured its economic by utilizing foreign aid. Foreign Aid generated economic growth and increased national performance. However, foreign aid in Afrika caused aid dependece to some countries. Ethiopia is one of the biggest aid recipient in Africa. In 2012, Ethiopia depended on foreign aid proven by 50\% of its national budget was from aid. Nonetheless, In 2017 Ethiopia reduced its dependence on aid in spite of still being a recipient. This research discusses Ethiopian strategies in escaping from aid dependence. The concept was initiated by Deborah Bräutigam dan Kwesi Botchwey. The results show thet Ethiopia experienced strong economic growth. Food security as the main issue and other development issues in Ethiopia could be resolved be donors. Donors had significant roles in making aid effectively. The collaboration amoing donors and other stakeholders was the key of aid project in Ethiopia. 


\section{PENDAHULUAN}

Bantuan luar negeri menjadi penting dalam perkembangan sebuah negara sejak tahun 1960an. Namun, isu tersebut memasuki babak baru dalam kepentingan politik sejak tahun 2000an. Hal ini bersamaan dengan dikeluarkannya Millenium Development Goals (MDGs) yang akan mencapai target pengentasan kemisikanan, peningkatan pendidikan, perbaikan kesehatan, pelestarian lingkungan, dan target lainnya yang akan dicapai pada tahun 2015 (Ann Veiderpass \& Per-Åke Andersson, 2007). Pada perkembangannya bantuan luar negeri tidak hanya menguntukan negara penerima, tapi juga memberikan keuntungan pada negara pendonor yang mayoritas merupakan negara maju (Deborah Bräutigam \& Kwesi Botchwey, 1999).

Sistem internasional yang membagi dunia menjadi negara-negara dengan high incomes atau disebut dengan North Countries dan negara-negara dengan low incomes atau disebut dengan South Countries. Pembiayaan kepada negara low incomes yang juga dikatakan sebagai negara berkembang dan kurang berkembang bisa dilakukan oleh negara dengan high incomes secara bilateral, melalui institusi multilateral seperti institusi yang dilahirkan melalui Bretton wood system, dan Non-Governmental Organizations.

Bantuan yang diterima dari negara donor dapat digunakan untuk menekan angka pajak untuk pendapatan ekonomi. Selain itu, bantuan juga dapat digunakan untuk mengurangi biaya ekonomi melalui kebijakan subsidi. Bagi negara penerima yang memiliki pemerintahan yang efektif, maka bantuan dapat dikelola untuk mengembangkan industri dan mencapai tujuan pembangunan dan ekonomi secara tepat sasaran. Contoh sukses penerima bantuan untuk perkembangan ekonomi adalah Korea dan Taiwan. Di tahun 1950an, Taiwan dan Korea menerima bantuan untuk membangun infrastruktur paska perang. Negara pendonor utamanya adalah Amerika Serikat. Bantuan AS tersebut digunakan untuk menekan kebijakan ekspor dan performansi ekonomi.

Di wilayah Afrika, situasi politik sejak kemerdekaan negara-negaranya tidak stabil. Implikasi dari politik yang tidak stabil adalah menurunnya pendapatan negara secara tajam. Sehingga banyak negara di wilayah tersebut bergantung pada bantuan asing untuk performansi ekonomi nasional (Deborah Bräutigam \& Kwesi Botchwey, 1999). Sejak tahun 1960an Afrika menjadi kawasan penerima bantuan luar negeri dengan jumlah yang besar. Lebih dari 600 milyar USD telah disalurkan di tahun 1960. 
Di tahun 2017, kawasan Afrika adalah penerima donor terbesar dibandingkan dengan benua lainnya. Dari total 162 milyar USD yang dikeluarkan untuk bantuan luar negeri, Afrika menerima sebesar 52 milyar USD dengan jumlah penduduk 1,2 milyar. Sedangkan pada urutan kedua adalah Asia yang menerima sebesar 48 milyar USD dengan jumlah penduduk 4,1 milyar. Negara pendonor di Afrika paling besar berasal dari Amerika Serikat (AS), Uni Eropa (UE), Britania Raya, Jerman, African Development Bank, Perancis, Jepang, dan Kanada. Adapun institusi multilateral yang menjadi donator adalah International Development Association (IDA), European Union (EU), Global Fund, African Development Fund, United Nations Children's Fund (UNICEF), International Monetary Fund (IMF), dan institusi multilateral lainnya (OECD, 2019).

Namun, efektifitas bantuan luar negeri di Afrika menjadi perdebatan dikarenakan Afrika tidak kunjung mencapai pertumbuhan yang baik. Di tahun 2014, masih terdapat 34 negara yang tergolong sebagai less developed countries (LDC) di Afrika. Hal tersebut didukung pula dengan ketidakmampuan pemerintah dalam mengelola bantuan luar negeri. Implikasinya adalah negara-negara di Afrika tergantung pada bantuan luar negeri untuk anggaran belanja nasional.

Salah satu penerima bantuan terbesar di Afrika adalah Etiopia. Etiopia adalah negara yang terletak di kawasan Afrika Timur. Etiopia merupakan salah satu negara dengan penerimaan dana bantuan luar negeri terbesar di Afrika. Bantuan menjadi penting bagi pemerintahan Etiopia. Di tahun 2010, bantuan difokuskan untuk mengembangkan pertanian skala besar dan juga sektor industri (Oakland Institute, 2013).

Di tahun 2011, Etiopia merupakan penerima terbesar bantuan bilateral dari Inggris sejumlah 261,8 juta USD. Selain dari Inggris, Etiopia juga menerima bantuan dari EU dan African Development Bank (ADB). Bantuan tersebut digunakan untuk sektor kesehatan, Pendidikan, dan air bersih (Akwagyiram, 2013). Di tahun ini juga, AS memberikan bantuan sebesar 608.3 juta USD kepada Etiopia (Oakland Institute, 2013).

Di tahun 2012, Etiopia menerima bantuan sebesar 3,5 milyar USD yang menyumbang lebih dari 50\% dari anggaran nasional. Bantuan tersebut paling banyak berasal dari Amerika Serikat (AS) melalui USAID, Bank Dunia, dan Inggris. Dengan nominal tersebut maka program pembangunan Etiopia sangat bergantung pada bantuan luar negerinya (Oakland Institute, 2013). 
Hingga di tahun 2017, Etiopia masih menerima bantuan dengan total sekitar 4,2 milyar USD. Pendonor utamanya adalah Bank Dunia dan AS. Di tahun ini, bantuan banyak dialokasikan untuk pembangunan infrastruktur dan bantuan kemanusiaan (OECD, 2017). Namun ditahun tersebut, alokasi bantuan yang diterima Etiopia hanya mencapai $6 \%$ dari PDB negara tersebut. Sehingga, Etiopia sudah berhasil beranjak dari keterpurukan ekonomi. Walaupun bantuan yang diterima Etiopia di tahun 2017 mencapai angka yang dapat dikategorikan sebagai ketergantungan terhadap bantuan, namun Etiopia masih tetap sebagai penerima terbesar dibanding negara-negara Afrika lainnya.

Deborah Bräutigam mengemukakan bahwa apabila 10\% pendapatan dan anggaran suatu negara berasal dari bantuan luar negeri, maka negara tersebut dikategorikan sebagai ketergantungan terhadap bantuan. Dari pemaparan diatas maka Etiopia mengalami masa panjang ketergantungan terhadap bantuan asing hingga mencapai 50\% dari anggaran nasionalnya. Namun di tahun 2017, Etiopia mampu melepaskan diri dari ketergantungan tersebut.

Penelitian ini membahas spesifik tentang strategi Etiopia dalam memanfaatkan bantuan asing demi meningkatkan pertumbuhan ekonomi nasional. Selain itu, penulis juga menganalisis strategi yang dilakukan Etiopia untuk menjadi negara yang tidak bergantung terhadap bantuan asing.

\section{KERANGKA TEORI}

Beberapa ahli meneliti tentang bagaimana ketergantungan pada bantuan terjadi di beberapa negara terutama di Afrika dan negara berkembang lainnya. Seperti penelitian berjudul Contested Sovereignty in Mozambique: The Dilemmas of Aid Dependence yang ditulis oleh Paolo De Renzio dan Joseph Hanlon. Mozambik menjadi ketergantungan terhadap bantuan luar negeri dikarenakan konflik internal yang dialami pada tahun 1992. Bantuan luar negeri yang diterima Mozambik mampu menurunkan angka kemiskinan walaupun berjalan sangat lambat. Penelitian ini membahas dilemma efektivitas bantuan asing yang diterima Mozambik beserta program apa saja yang diselipkan dalam bantuan untuk meningkatkan pertumbuhan negara tersebut (Paolo De Renzio \& Joseph Hanlon, 2007). 
Berikutnya penelitian berjudul Determinants of 'Exit' from High Aid-Dependence yang ditulis oleh Degol Hailu dan Admasu Shiferaw. Penelitian ini melihat adanya negara yang masih bergantung pada bantuan untuk rasio GDP. Temuan penelitian menyatakan bahwa peningkatan investasi tidak mengurangi negara untuk bergantung pada bantuan luar negeri di Afrika (Degol Haliu \& Admasu Shiferaw, 2016).

Penelitian berikutnya ditulis oleh Willem Paling yang berjudul Planning Future for Phnom Penh: Mega Projetcs, Aid Dependence, and Disjointed Governance. Penelitian Willem Paling berfokus pada analisa keterlibatan aktor internasional dalam pembangunan di Phnom Penh, Kamboja. Keterlibatan internasional yang dimaksud adalah donor internasional yang tergolong aktor swasta. Mereka berkontribusi terhadap perkembangan, pembangunan, dan pengetahuan tentang tata kota (Paling, 2012).

Selanjutnya adalah sub bab buku yang memaparkan tentang Ghana: Breaking Out of Aid Dependence? Economic and Political Barriers to Ownership. Ditulis oleh Rachel Hayman di dalam buku berjudul The Politics of Aid African Strategies for Dealing with Donors. Ghana mengalami krisis ekonomi di awal kemerdekaannya sehingga membuat Bank Dunia, IMF, dan negara-negara maju memberikan dukungan. Hayman menjelaskan bagaimana politik bantuan luar negeri yang diterima Ghana dalam menentukan agenda kebijakan nasional akibat dari ketergantuanya terhadap bantuan (Lindsay Whitfield \& Emily Jones, 2009).

Penelitian berikutnya yang menjadi acuan dalam penelitian ini adalah tulisan berjudul Aid Dependence, Sustainability, and Technical Assistance, Designing a Monitoring and Evaluation System in Tanzania. Penelitian tersebut ditulis oleh David Hirschmann. Penelitian tersebut menjelaskan tentang debat antara ketergantungan bantuan asing dan kepemilikan. Program bantuan yang tergolong dalam bantuan teknis mempengaruhi performansi Tanzania termasuk penguatan institution building, partisipasi pemerintah, dan aspek teknis lainnya yang dibutuhkan untuk restrukturisasi (Hirschmann, 2003).

\section{Foreign Aid}

Bantuan luar negeri bertujuan untuk mempromosikan perkembangan negara penerima. Fenomena ini menjadi kebijakan luar negeri negara maju di era modern. Kebijakan ini menjadi signifikan paska berakhirnya perang dunia ke dua. Restrukturisasi Eropa dalam program Marshall Plan merupakan salah satu contoh keberhasilan kebijakan tersebut. 
Dalam pandangan realis, kebijakan dalam memberikan bantuan luar negeri adalah sebuah instrumen untuk kekuatan politik. Sedangkan dalam pandangan liberalis, bantuan berimplikasi pada perkembangan negara penerima melalui penyelesaian masalah yang disebabkan oleh globalisasi. Sedangkan paham marxis mengemukakan teori dependensi yang disebabkan oleh bantuan asing. Bagi paham ini, bantuan merupakan alat negara maju untuk dapat mengeksploitasi negara berkembang. Lain hal dengan konstruktivis yang menekankan bahwa bantuan luar negeri merupakan tindakan moral negara maju untuk peningkatan taraf hidup negara miskin (Lancaster, 2007).

Namun, bantuan luar negeri tidak lepas dari kritik dan kontroversi. Kritik utama dalam fenomena bantuan luar negeri adalah keefektifan dari bantuan tersebut. Bantuan luar negeri dapat mengentaskan kemiskinan dan meningkatkan pertumbuhan, namun disisi lain dapat menyesatkan negara penerima dalam keterpurukan.

\section{Aid Dependence}

Menentukan ketergantungan kepada bantuan luar negeri tidak hanya sekedar melihat pada indikator kemiskinan pada suatu negara. Terkadang, negara yang memiliki pendapatan rendah tidak memiliki ketergantungan pada bantuan. Aid dependence adalah bantuan luar negeri yang diberikan kepada penerima bantuan dimana bantuan tersebut menjadi faktor utama dalam performansi ekonomi nasional. Sehingga untuk mengukur ketergantungan pada bantuan adalah melihat persentase bantuan yang diterima dengan GDP yang diperoleh.

Sehingga, secara singkat aid dependence adalah situasi dimana negara tidak dapat melaksanakan operasional domestic tanpa mengandalkan bantuan luar negeri. Apabila bantuan luar negeri mencapai 10\% pendapatan nasionalnya (Bräutigam, 2000). Negara dapat tergantung pada bantuan secara jangka Panjang ataupun sementara. Ketergantungan pada bantuan dapat dikarenakan konflik domestik seperti perang, ketidakstabilan politik, dan krisis ekonomi.

\section{Strategi dalam Mengurangi Ketergantungan terhadap Bantuan}

Bantuan akan menjadi efektif jika pemerintah tersebut mampu untuk mengelola dengan baik. Jika negara yang menerima bantuan memiliki kebijakan makroekonomi yang buruk dan terdapat ketidakstabilan politik maka bantuan tidak akan berdampak pada perkembangan. Pemberi bantuan dapat memberikan dukungan melalui pelatihan kepada stakeholder untuk perubahan secara struktural, namun jika institusi lokal tidak mendukung 
adanya akuntabilitas, partisipasi, dan birokrasi yang efektif maka bantuan tidak akan memberikan dampak signifikan.

Keberhasilan bantuan luar negeri juga ditentukan pada proses internasional demokrasi negara penerima. Pada kasus Afrika, bantuan yang diberikan semakin membuat negara bergantung terhadap bantuan tersebut. Sehingga diperlukan reformasi terhadap metode pemberian bantuan.

Oleh karena itu, Bräutigam mengadvokasi strategi bagi negara-negara Afrika agar dapat keluar dari ketergantungan terhadap dana bantuan asing. Strategi tersebut adalah increased debt relief, greater ex post selectivity, abandon the project of mode of aid delivery and switch to program support, establish demand-driven foundations, and basic capacity strenghthening, dan Establish a Credible Timetable for the Eventual Termination of Program Aid.

Pertama, increased debt relief. Beberapa institusi multilateral sudah memberikan keringanan hutang bagi negara-negara Afrika. Bank Dunia memiliki program untuk memberikan keringanan hutang bagi negara yang dikategorikan sebagai Heavily Indebted Poor Countries (HIPC). Inisiatif ini juga bisa menjadi pengampunan bagi proyek-proyek bantuan yang dikatakan sebagai proyek yang gagal namun menyisakan hutang bagi negara penerima.

Kedua, greater ex post selectivity. Strategi kedua adalah bantuan luar negeri harus sinergis dengan kebijakan kebijakan pembangunan yang efektif. Sehingga, donatur harus selektif dalam memberikan bantuan melalui mekanisme komitmen. Hal tersebut berhasil diterapkan di Botswana, Mauritius, Taiwan dan Korea Selatan. Selektivitas terhadap pemberian bantuan didasari oleh stabilitas makroekonomi dan kondisi politik domestik. Sebagai contoh, liberalisasi pasar di Asia Timur menyebabkan bantuan luar negeri dapat dimanfaatkan untuk menstimulasi ekspor dan meningkatkan pertumbuhan ekonomi. Selain itu, selektivitas juga didasari oleh bukti bahwa negara penerima bantuan mampu untuk memenuhi prinsip akuntabilitas, mengatur anggaran dengan baik, pembelanjaan yang transparan, memiliki rencana jangka menengah yang rasional dengan memanfaatkan sumber daya dengan efisien.

Ketiga, abandon the project of mode of aid delivery and switch to program support. Apabila selektivitas telah dilakukan oleh para pendonor dan negara penerima, maka selanjutnya adalah memilih bentuk program bantuan. Salah satu contohnya adalah bantuan 
teknis dan program kerjasama ekonomi. Dengan tidak lagi menerima pendanaan, maka proyek teknis dapat membantu negara berkembang untuk mandiri dalam mengimplementasikan rencana sektoral dan proyek-proyek.

Keempat, establish demand-driven foundations, and basic capacity strenghthening. Strategi keempat muncul karena terdapat kemungkinan besar negara-negara Afrika tidak dapat memenuhi kriteria pada strategi kedua dan ketiga. Sehingga Bräutigam menawarkan dua strategi agar negara berkembang dapat keluar dari ketergantungan bantuan. Yang pertama adalah pemberian donor kepada satu kawasan yang dilakukan oleh banyak donor. Mekanisme ini dapat dilakukan dengan pengajuan proposal oleh individu atau kelompok individu di masyarakat atau bisa diwadahi oleh organisasi non profit) baru kemudian terjadi pendanaan berdasarkan kebutuhan secara regional. Hal ini meminimalisir peran pemerintah yang kurang kapabilitas dalam mengelola bantuan. Kedua adalah penguatan kapasitas dasar meliputi komitmen jangka panjang terhadap sumber daya manusia dan pengentasan permasalahan regional. Sistem ini mengacu pada peningkatan kapasitas pada sektor pendidikan, agrikultur, teknologi, dan kesehatan dengan komitmen jangka panjang.

Kelima, basic capacity strenghthening, dan Establish a Credible Timetable for the Eventual Termination of Program Aid. Bantuan luar negeri harus bertujuan untuk peningkatan kemampuan negara di pasar internasional. bantuan luar negeri juga ditujukan untuk mempromosikan negara penerima sebagai tujuan investasi asing. Untuk mencapai tujuan tersebut, maka diperlukan adanya jadwal penghentian bantuan yang dilakukan secara bertahap. Sehingga dalam fase tahapan penghentian bantuan, iklim yang dibangun adalah iklim promosi perdagangan dan investasi (Deborah Bräutigam \& Kwesi Botchwey, 1999).

\section{METODOLOGI PENELITIAN}

Pendekatan penelitian ini adalah kualitatif dengan jenis penelitian studi dokumentasi. Penelitian ini berusaha untuk memberikan gambaran secara menyeluruh mengenai tinjauan strategis dalam memandang fenomena ketergantungan bantuan asing yang dialami Etiopia. Teknik pengumpulan data yang digunakan dalam penelitian ini adalah library research. Dimana dalam teknik pengumpulan ini, data-data baik primer maupun sekunder sebagai pendukung. Dimana sumber daya tersebut memiliki keterkaitan dengan tema kekuatan korporasi dalam tuduhan lingkugan, yang diperoleh melalui literatur cetak maupun elektronik yang berupa buku, artikel, majalah, jurnal, koran, serta laporan kerjasama dari 
sumber yang kridibel.. Teknik analisa data yang digunakan adalah teknik analisa deduktif, dimana data-data diperoleh melalui dalil umum, postulat, dan paradigma tertentu yang kemudian dihubungkan dengan data-data empiris yang menajdi titik pengambilan kesimpulan dari data tersebut. Beberapa data yang berkenaan dengan angka, akan diterjemahkan ke dalam bentuk verbal. Dalam penelitian ini, data-data yang berkaitan dengan variabel dalam bantuan luar negeri dan kebijakannya direduksi dan dipilah kembali untuk dicari kesesuaian dengan kebutuhan data sebagai pendukung untuk menjawab pertanyaan penelitian terkait dengan strategi Etiopia mengurangi ketergantungan terhadap bantuan asing.

\section{PEMBAHASAN}

\section{Economic Development in Etiopia}

Etiopia adalah negara dengan landlocked area yang berada di wilayah Afrika Timur. Etiopia mengandalkan negara tetangganya yaitu Djibouti dan Eritrea sebagai Pelabuhan perdagangan internasionanya (World Bank, 2019). Etiopia merupakan salah satu negara dengan penduduk terbanyak di Afrika. Pada tahun 2018 penduduknya berjumlah 109 juta. Hal ini membuat Etiopia memiliki populasi terbesar ke dua setelah Nigeria (World Bank, 2019).

Rata-rata pertumbuhan ekonomi Etiopia sejak tahun 2008 hingga tahun 2018 adalah sebesar 9.9\%. Etiopia mengalami pertumbuhan ekonomi yang cukup baik sejak tahun 2013. Adapun GDP di tahun 2013 mencapai 47,6 milyar dolar dan GDP di tahun 2018 sebesar 84,3 milyar dolar.

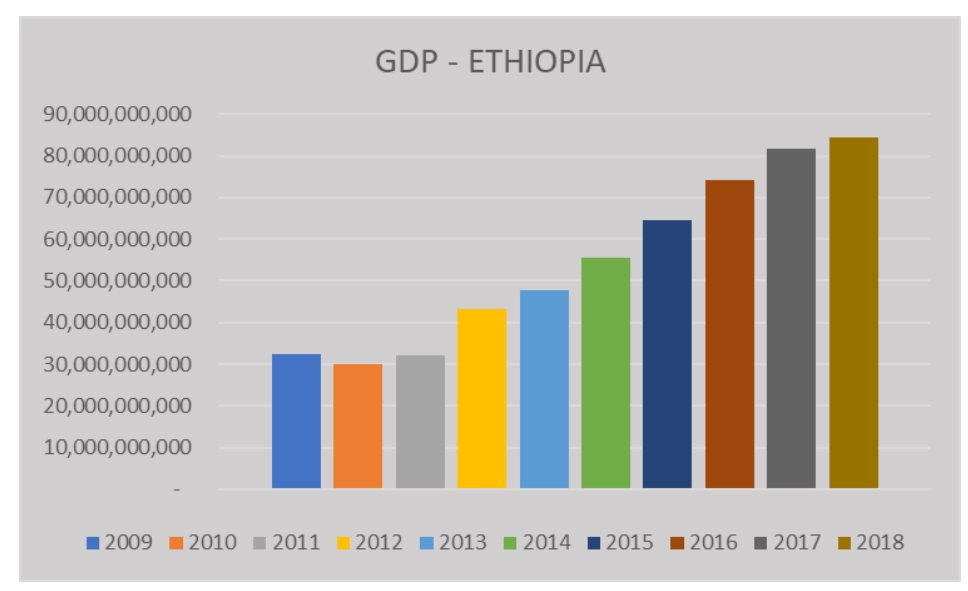

Grafik 1. GDP Etiopia

Sumber: (World Bank, 2019) 
Jika dibandingkan dengan negara di kawasan Afrika Timur lainnya, ekonomi Etiopia menempati posisi tertinggi kedua setelah Kenya jika dilihat dari besaran GDP masingmasing negara sejak tahun 2008.

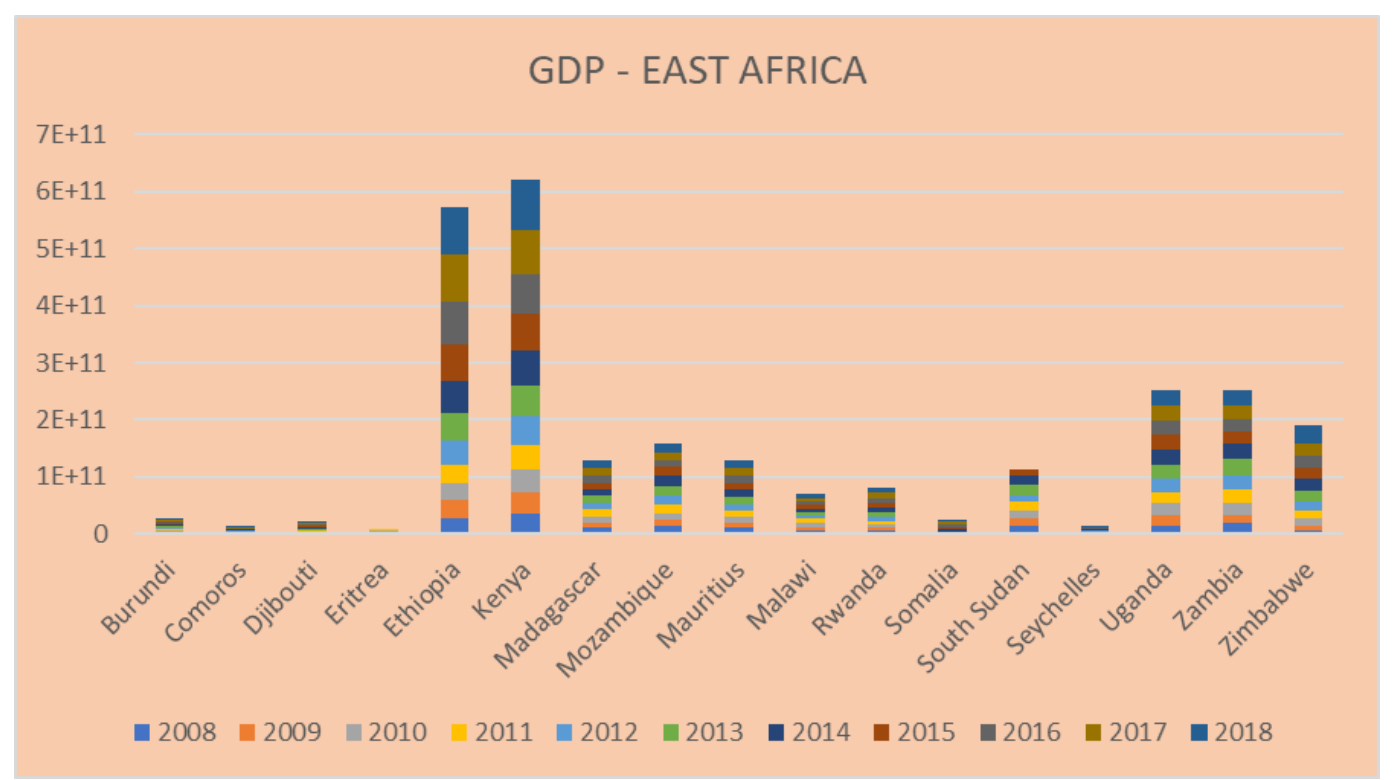

Grafik 2. GDP Afrika Timur

Sumber: (World Bank, 2019)

Komoditas unggulan dari Etiopia adalah sereal, kopi, kapas, sayuran, daging kambing, perikanan, dan hasil pertanian lainnya. Sedangkan industri paling kuat ada pada sector pengelolaan makanan, tekstil, bahan kimia, semen, dan beberapa industri lainnya. Etiopia mengekspor komoditasnya mayoritas ke negara-negara seperti Sudan, Swiss, China, Somalia, Belanda, Amerika Serikat, Jerman, Arab Saudi, dan UK. Adapun total nilai ekspor di tahun 2016 adalah 2.8 milyar dolar dan meningkat di tahun 2017 sebesar 3.23 milyar dolar. Namun, nilai ekspor Etiopia jauh lebih sedikit dibanding nilai impornya. Pada tahun 2016 total nilai impor Etiopia sebesar 14.69 milyar dolar dan di tahun 2017 meningkat hingga 15.59 milyar dolar. Etiopia mengimpor beberapa komoditas seperti minyak bumi, electric materials, mesin, kendaraan, dan produk baja (CIA, 2019).

Selain itu, Etiopia mengalami krisis politik yang berdampak pada aktivitas ekonomi nasionalnya. Etiopia memiliki konflik perbatasan dengan Eritrea sejak tahun 1998. Perselisihan ini berlangsung hingga 2018, Perserikatan Bangsa-bangsa (PBB) telah menyerahkan tanah Eritrea. Perang dengan Eritrea bukan satu-satunya penyebab ketidakstabilan politik di Etiopia (Utomo, 2018). Politik domestik Etiopia juga mengalami 
banyak perselisihan seperti krisis paska pemilu, kontrol rezim yang kuat oleh Meles Zenawi (Clapham, 2009), dan protes masyarakat yang terjadi pada tahun 2016.

Beberapa konflik tersebut berpengaruh kepada perkembangan di Etiopia. Pada tahun 2000, Etiopia termasuk dalam kategori negara termiskin ketiga didunia. 50\% penduduk Etiopia berada pada garis kemiskinan. Padahal Etiopia memiliki jumlah penduduk terbesar kedua di Afrika (African Union, 2019).

\section{Bantuan Luar Negeri di Ethiopia}

Etiopia merupakan salah satu penerima bantuan terbesar di Afrika. Pendonor datang secara bilateral dan multilateral. Negara yang melakukan donor kepada Etiopia antara lain Amerika Serikat, Inggris, Jepang, China, dan lainnya. Sedangkan institusi yang memberikan bantuan antara lain Bank Dunia, IMF, Uni Eropa, dan lain-lain. Pada bab ini penulis memberikan gambar secara ringkas terkait bantuan yang di terima oleh Etiopia baik secara bilateral dan multilateral.

Paska perang dunia ke 2, Amerika Serikat (AS) telah berkomitmen untuk menjalin hubungan ekonomi. Melalui United States Agency for International Development (USAID), AS memprioritaskan bantuan untuk perkembangan di Etiopia. Pada tahun 1961, fokus AS memberikan bantuan di sector pertanian, Pendidikan, Kesehatan, pertambangan dan beberapa sektor utama lainnya. Hingga tahun 1990 terdapat pergeseran fokus bantuan dengan mengutamakan demoktrasi, reformasi ekonomi, dan privatisasi tanpa melepaskan inisiatif di bidang Kesehatan, Pendidikan, dan ketahanan pangan. Kemudian AS membangun strategic objectives dalam bantuannya, dimana tujuan ini berubah secara berkala mengikuti perkembangan Etiopia dan Ekonomi Global. Hingga tahun 2011, AS memiliki strategic objectives dalam bantuannya ke Etiopia yang meliputi Peace and Security, Governing Justly, Investing In People, Economic Growth, dan Humanitarian Assistance (USAID, 2020). Pada tahun 2008, AS memberikan bantuan dengan total sebesar 765 juta dolar. 


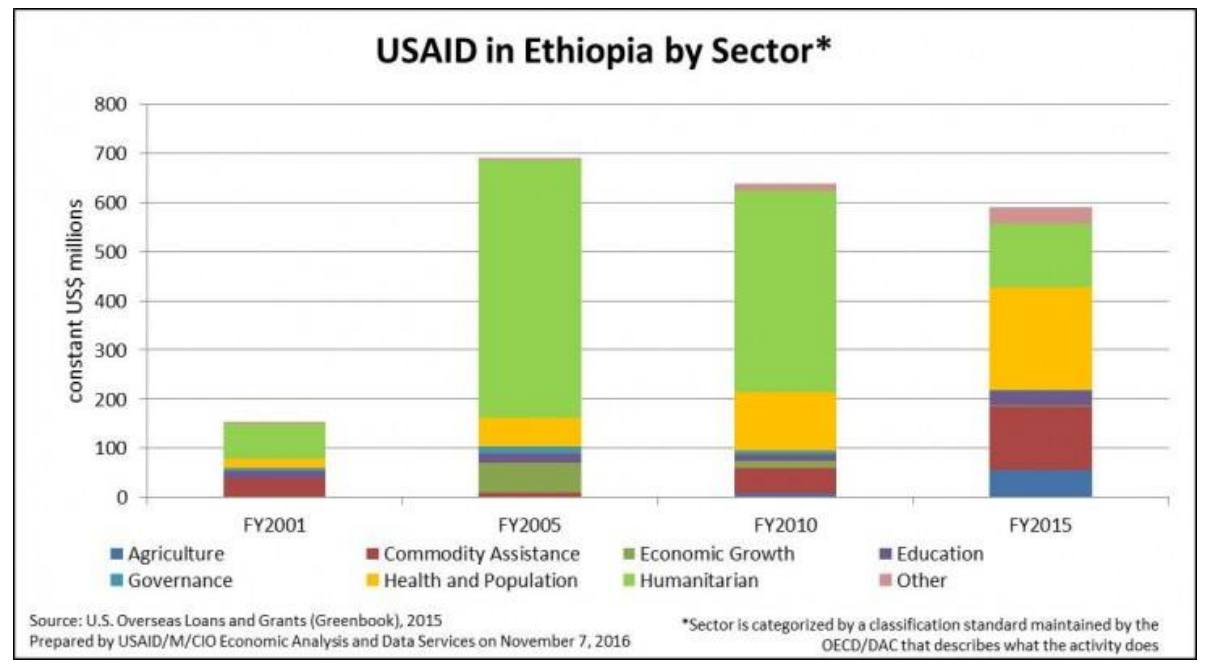

Grafik 3. Bantuan Luar Negeri AS ke Etiopia Melalui USAID Sumber: (USAID, 2020)

Inggris memiliki kontribusi kuat bagi perkembangan di Etiopia melalui bantuan berupa proyek maupun dana sejak tahun 1990an. Pada sektor kesehatan, Pemerintah Inggris melalui Commonwealth and Development Office memberikan dana bantuan sebesar 275 juta poundsterling. Dana tersebut dialokasikan untuk memberikan sektor kesehatan diantaranya sektor reproduksi, control malaria, perencanaan keluarga, dan control terhadap penyakit yang meginfeksi masyarakat. Program bantuan ini dimulai sejak 2011 dan selesai di tahun 2015 (UK Aid, 2016). Bantuan di sektor pangan juga diberikan pada tahun 2004 hingga 2009. Bantuan ini berupa bantuan teknis dan peningkatan kapasitas. Bantuan yang diberikan senilai 1,9 juta poundsterling. Tidak hanya itu, Inggris juga fokus dalam memberikan bantuan dibidang pertanian yang dibuktikan dengan memberikan bantuan sejumlah 2 juta poundsterling. Bantuan ini digunakan untuk mengembangkan kebijakan tentang pertanian, pengelolaan sumber daya, penelitian, dan bantuan pangan.

Pemerintah Inggris juga memberikan bantuan secara bilateral ke Etiopia yang bersifat multi sektor. Bantuan sejumlah 122 juta poundsterling diberikan sejak 2013 hingga saat ini untuk membantu Etiopia di bidang lingkungan, kesehatan, air minum, sanitasi, kesetaraan gender dan sektor lainnya. Inggris melalui bantuannya bertujuan untuk mereduksi kemiskinan, ketidakstabilan kawasan, dan permasalahan migrasi.

EU juga berkontribusi pada bantuan luar negeri di Etiopia baik secara institusi ataupun bilateral dari negara anggotanya.Selain bantuan EU juga memiliki serangkaian kegiatan ekonomi dengan Etiopia di sektor perdagangan dan investasi untuk peningkatan 
pembangunan di Etiopia. Di antaranya adalah inisiasi Everything But Arms yang berkaitan dengan pembebasan pajak impor dan kuota.

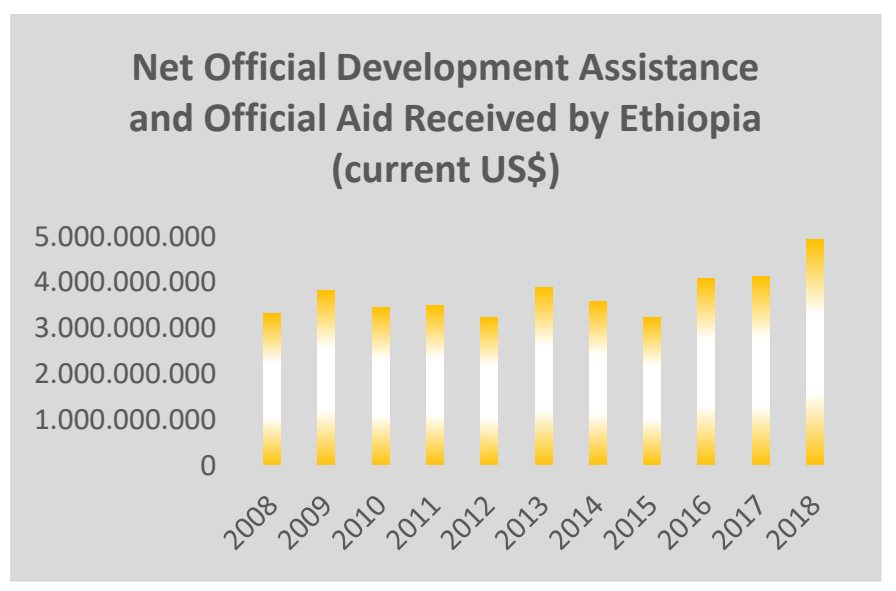

\section{Grafik 4. Data Bantuan Luar Negeri Bamk Dunia di Etiopia}

Source: (The World Bank, 2020)

Berdasarkan data dari Bank Dunia, Etiopia memiliki total penerimaan bantuan sebesar 3.8 Milyar US Dolar pada tahun 2009. Etiopia juga mengalami permasalahan keamanan pangan. Kemiskinan dan kelaparan menjadi permasalahan utama sejak tahun 1974. Sejak itu, Etiopia menerima bantuan pangan selama berpuluh-puluh tahun. Hingga tahun 2011, Etiopia masih mengalami krisis pangan yang menjadikan bantuan terus digulirkan ke negara tersebut. Bantuan selama puluhan tahun tidak berimplikasi pada peningkatan ketahanan pangan Etiopia namun menjadikan Etiopia sebagai negara dengan ketergantungan bantuan pangan terparah di dunia (Aschale Dagnachew Siyoum, Dorothea Hilhorst, Gerrit-Jan Van Uffelen, 2012).

Melalui International Development Association (IDA), Bank Dunia memberikan bantuan sejumlah 640 juta US Dolar pada tahun 2011. Dari total bantuan tersebut, sejumlah 420 juta US Dolar digunakan untuk Basic Services Program (PBS) meliputi Pendidikan, pertanian, pengairan, kesehatan, dan konstruksi jalan. Program ini juga didukung oleh USAID dalam implementasinya.

\section{Ketergantuan Bantuan Luar Negeri di Etiopia}

Etiopia merupakan penerima donor terbesar di wilayah sub sahara Afrika sejak tahun 1980. Pada tahun 2010, Etiopia dikategorikan sebagai penerima bantuan makanan terbesar yaitu sejumlah 1,2 Milyar Dolar. Oakland Institute, berdasarkan penelitiannya mengemukakan bahwa Etiopia negara berkembang dengan status sangat bergantung dengan bantuan asing (Oakland Institute, 2013). 
Ketergantungan bantuan di Etiopia disebabkan oleh banyak hal. Salah satunya adalah tentang perubahan perilaku masyarakat sebagai penerima bantuan. Mental masyarakat yang menerima bantuan di Etiopia (khususnya pada program bantuan pangan dan pertanian) tidak dapat meningkatkan performansi pertanian di beberapa wilayah. Dengan kata lain tingkat produktivitas hasil pangan tetap rendah dan mengutamakan bantuan untuk memenuhi kebutuhan pangan (Aschale Dagnachew Siyoum, Dorothea Hilhorst, Gerrit-Jan Van Uffelen, 2012).

\section{Strategi Etiopia dalam Mengurangi Ketergantungan Terhadap Bantuan Luar Negeri}

Pada tahun 2005, IMF menyetujui adanya pengampunan hutang secara menyeluruh atau sejumlah 161 juta US Dolar. Hal ini dikarenakan pengkategorian Etiopia sebagai Heavily Indebted Poor Countries (HIPC). IMF berharap dengan debt relief tersebut, Etiopia bisa mencapai tujuan dari Millenium Deveopment Goals (MDG) (IMF, 2005). Selain Etiopia, IMF juga membebaskan hutang bagi Bolivia, Burkina Faso, Kamboja, Ghana, Guyana, Honduras, Madagaskar, dan negara HIPC lainnya. Etiopia juga pernah menerima paket pembebasan pinjaman atas rekomendasi bank dunia dan IMF.

bantuan asing di Etiopia juga di evaluasi oleh para pendonornya termasuk di dalamnya lembaga independen atau konsultan bahkan juga dievaluasi oleh lembaga yang terdiri dari masyarakat sipilnya. Organisasi Bank Dunia juga pernah melakukan evaluasi terkait efektivitas dari bantuan yang diberikan.

Dalam mengelola bantuan, pemerintah Etiopia memiliki Aid Management Platform (AMP) untuk melaporkan proses pertumbuhan nasional. Program ini dimulai tahun 2005 ketika Etiopia mengalami urgensi dalam menerima bantuan terutama untuk kemiskinan. Melalui program ini, Etiopia dapat merekap bantuan asing dari seluruh pendonor yang masuk dan melihat efektivitas dari bantuan tersebut. Program ini merukapan kerjasama antara Development Gateaway dengan Kementerian Keungan dan Pertumbuhan Ekonomi Etiopia (Development Gateaway, 2012).

Namun, bantuan yang masuk di Etiopia lebih banyak evaluasi dari negara pendonor ataupun institusi multilateral. Jepang sebagai salah satu pendonor melakukan evaluasi yang dipublikasi oleh kementerian luar negerinya. Pada tahun 2010, Jepang memaparkan lima tujuan strategis dalam memberikan donor ke Etiopia adalah sektor pertanian, sumber daya air. Infrastruktur, pendidikan, dan kesehatan. Jepang melakukan kombinasi antara bantuan 
hibah dan bantuan teknis. Evaluasi yang dilakukan Jepang memiliki tiga kriteria. Ketiga kriteria tersebut adalah relevansi kebijakan, efektifitas hasil bantuan, dan kesesuaian proses.

Berdasarkan kriteria pertama, kebijakan dasar Jepang dalam memberikan bantuan adalah keamanan pangan. Hal tersebut dituangkan dalam bantuan berupa proyek penguatan petani di daerah Oromia. Proyek ini membantu petani untuk memproduksi pangan dengan teknologi yang efisien. Proyek tersebut merupakan kolaborasi pemerintah jepang dengan Bank Dunia. Namun, jepang mengevaluasi bahwa hingga tahun 2010 masih ada proyek yang tidak sesuai dengan tujuan dasarnya mengenai kebutuhan pangan.

Kriteria kedua membahas tentang efektifitas hasil bantuan. Kebijakan keamanan pangan terbagi atas lima tujuan strategis yang telah dijelaskan pada paragraf sebelumnya. Pada sektor pertanian, jepang fokus pada pembangunan irigasi, penguatan distribusi hasil pertanian, dan transfer teknologi pengeolaan pertanian. Pada sektor sumber daya air, jepang mendirikan sentra pelatihan bernama Etiopian Water Technology Center (EWTEC). Dalam pengelolaan sentra ini, terdapat kolaborasi dengan aktor privat dan aktor non pemerintah. Pada sektor pendidikan, jepang lebih banyak memberikan bantuan hibah kepada sekolah hingga di area terpencil. Pada sektor kesehatan, Jepang memberikan bantuan terkait pengentasan penyakit serius dan peningkatan gizi. Proyek pada sektor kesehatan merupakan hasil kolaborasi Jepang dengan United Nations International Children's Emergency Fund (UNICEF) dan Bank Dunia. Berdasarkan penjelasan upaya menghasilkan bantuan yang efektif, ternyata Etiopia masih mengalami separuh jalan menuju keamanan pangan. Etiopia membutuhkan sumber yang tidak hanya berbasiskan pertanian.

Kriteria ketiga adalah tentang kesesuaian pada proses bantuan. Pada bantuan berjenis dana hibah, terdapat kendala implementasi pada pihak Etiopia. Ada beberapa yang gagal dan tertunda. Jepang juga erlu berpartisipasi kuat pada dialog kebijakan dan pengkajian ulang terkait dampak bantuan yang diberikan jepang ke Etiopia (The Ministry of Foreign Affairs of Japan, 2010).

Bantuan di bidang keamanan pangan juga dilakukan oleh Bank Dunia bersama partner lainnya seperti USAID, Irish Aid, Canadian International Development Agency, World Food Program, Swedish International Development Agency, dan lainnya. Mereka berdonasi untuk National Food Security Program (NFSP) di Etiopia. Selain itu, NGO memiliki peran untuk mendistribusikan program ini ke pemerintah daerah (Flores, 2013). 
NGO yang terlibat dalam implementasi bantuan di Ethiopia antara lain CARE Ethiopia, Catholic Relief Services, World Vision, Save the Children, dan organisasi non profit lainnya yang berasal dari Jerman. Salah satu organisasi non pemerintah yang berasal dari Jerman adalah Deutsche Welthungerhilfe atau German Argo Action. Organisasi tersebut telah aktif di Etiopia untuk memerangi kemiskinan melalui dana yang diberikan selama puluhan tahun di Etiopia. Sedangkan organisasi non pemerintah yang menjadi payung besar organisasi masyarakat di Etiopia adalah Christian Relief and Development Association (CCRDA). CCRDA berperan pada sektor keamanan pangan, kesehatan, lingkungan, pendidikan, air dan sanitasi, serta sektor lainnya. CCRDA berfungsi memberikan pelayanan dan advokasi kebijakan (Abeselom, 2018).

\section{KESIMPULAN}

Peran institusi dan negara pendonor lebih besar dalam mengelola bantuan jika dibandingkan dengan usaha yang dikeluarkan Etiopia. Pemerintah Etiopia memiliki peran melalui serangkaian kebijakan. Namun, evaluasi dari program bantuan lebih ditekankan kepada peran pendonor. Dalam hal ini dapat disimpulkan bahwa, keberhasilan Etiopia dalam melepaskan dari ketergantungan bantuan luar negeri

\section{DAFTAR PUSTAKA}

\section{Buku:}

Lindsay Whitfield \& Emily Jones. (2009). Ghana: Breaking Out of Aid Dependence? Economic and Political Barriers to Ownership. In L. Whitfield, The Politics of Aid African Strategies for Dealing with Donors (pp. 185-216). New York: Oxford University Press.

Lancaster, C. (2007). Foreign Aid: Diplomacy, Development, Domestic Politics. Chicago: The University of Chicago Press.

\section{Jurnal:}

Bräutigam, D. (2000). Aid Dependence and Governance. California: Almqvist \& Wiksell International.

Clapham, C. (2009). Post-war Ethiopia: The Trajectories of Crisis. Review of African Political Economy, 181-192.

Deborah Bräutigam \& Kwesi Botchwey. (1999). The institutional impact of aid dependenee on recipients in Africa. CMI Working Papers. 
Degol Haliu \& Admasu Shiferaw. (2016). Determinants of 'Exit' from High AidDependence. Journal of African Economies, , Vol. 25, number 5, 670-698.

Hirschmann, D. (2003). Aid dependence, sustainability and technical assistance Designing a monitoring and evaluation system in Tanzania David Hirschmann. Public Management Review, Vol. 5, Issue 2.

Aschale Dagnachew Siyoum, Dorothea Hilhorst, Gerrit-Jan Van Uffelen. (2012). Food aid and dependency syndrome in Ethiopia: Local perceptions. The Journal of Humanitarian Assistance.

Paling, W. (2012). Planning a Future for Phnom Penh: Mega Projects, Aid Dependence and Disjointed Governance. Urban Studies Jurnal, Vol. 49, Issue 13.

\section{Laporan:}

Ann Veiderpass \& Per-Åke Andersson. (2007). Foreign Aid, Economic Growth and Efficiency Development. Karlstad: Swedish Agency for Development Evaluation.

Flores, L. (2013). Development Aid to Ethiopia. Oakland: Oakland Institute.

Oakland Institute. (2013). Development Aid to Ethiopia Overlooking Violence, Marginalization, and Political Repression. Oakland: Oakland Insitute.

OECD. (2019). Development Aid at A Glance . OECD.

Paolo De Renzio \& Joseph Hanlon. (2007). Contested Sovereignty in Mozambique: The Dilemma of Aid Dependence. GEG Working Paper.

The Ministry of Foreign Affairs of Japan. (2010). Country Assistance Evaluation of Ethiopia. The Ministry of Foreign Affairs of Japan.

\section{Sumber Online:}

African Union. (2019, April 6). "Ethiopia", Negara Miskin Yang Kini Telah Berkembang. Retrieved from African Economic Cooperation Blog: http://www.africanunion.org/ethiopia-negara-miskin-yang-kini-telah-berkembang/

Akwagyiram, A. (2013, Mei 1). How can Africa move away from aid dependence? Retrieved from BBC News: https://www.bbc.com/news/world-africa-22270164

CIA. (2019). The World Factbook. Retrieved from Central Intelligence Agency: https://www.cia.gov/library/publications/the-world-factbook/geos/et.html

Development Gateaway. (2012, Desember 12). Development Gateway Extends Support in Ethiopia. Retrieved from Development Gateaway:

https://developmentgateway.org/blog/development-gateway-extends-support-inethiopia/

IMF. (2005, December 23). Press Release: IMF to Extend 100 Percent Debt Relief to Ethiopia Under the Multilateral Debt Relief Initiative. Retrieved from International Monetary Fund: https://www.imf.org/en/News/Articles/2015/09/14/01/49/pr05292 
OECD. (2017). Gross disbursements of Official Development Assistance (ODA) in 2017. Retrieved from Compare your country: https://www2.compareyourcountry.org/aidstatistics?cr=238\&lg=en \&page $=31$

The World Bank. (2020). https://data.worldbank.org/indicator/DT.ODA.ALLD.CD. Retrieved from The World Bank:

https://data.worldbank.org/indicator/DT.ODA.ALLD.CD

UK Aid. (2016, Oktober 4). Support for the Ethiopian Health Sector Development Programme. Retrieved from UK Aid Development Tracker: https://devtracker.fcdo.gov.uk/projects/GB-1-202990

USAID. (2020, April 17). History of USAID in Ethiopia. Retrieved from USAID: https://www.usaid.gov/ethiopia/history-usaid-ethiopia

Utomo, H. F. (2018, July 10). Pelukan Mengakhiri Perang Antara Pemimpin Ethiopia dan Eritrea Selama 20 Tahun. Retrieved from Liputan 6: https://www.liputan6.com/global/read/3583616/pelukan-mengakhiri-perang-antarapemimpin-ethiopia-dan-eritrea-selama-20-tahun

World Bank. (2019). GDP (Current US\$) - Ethiopia. Retrieved from The World Bank: https://data. worldbank.org/indicator/NY.GDP.MKTP.CD?end=2018\&locations=E T\&start $=2008$

World Bank. (2019, September 26). The World Bank in Ethiopia. Retrieved from The World Bank: https://www.worldbank.org/en/country/ethiopia/overview 